\title{
Metastatic genes targeted by an antioxidant in an established radiation- and estrogen-breast cancer model
}

\author{
GLORIA M. CALAF ${ }^{1,2}$ and DEBASISH ROY ${ }^{3}$ \\ ${ }^{1}$ Instituto de Alta Investigación, Universidad de Tarapacá, Arica, Chile; ${ }^{2}$ Center for Radiological Research, \\ Columbia University Medical Center, New York, NY; ${ }^{3}$ Department of Natural Sciences, \\ Hostos College, The City University of New York, Bronx, NY, USA
}

Received March 16, 2017; Accepted August 23, 2017

DOI: $10.3892 / \mathrm{ijo} .2017 .4125$

\begin{abstract}
Breast cancer remains the second most common disease worldwide. Radiotherapy, alone or in combination with chemotherapy, is widely used after surgery as a treatment for cancer with proven therapeutic efficacy manifested by reduced incidence of loco-regional and distant recurrences. However, clinical evidence indicates that relapses occurring after radiotherapy are associated with increased metastatic potential and poor prognosis in the breast. Among the anticarcinogenic and antiproliferative agents, curcumin is a well-known major dietary natural yellow pigment derived from the rhizome of the herb Curcuma longa (Zingiberaceae). The aim of the present study was to analyze the differential expression of metastatic genes in radiation- and estrogen-induced breast cancer cell model and the effect of curcumin on such metastatic genes in breast carcinogenesis. Expression levels of TGF- $\alpha$ and TGF $\beta 1$ genes were upregulated in $\mathrm{MCF}-10 \mathrm{~F}$ and downregulated in Tumor 2 cell lines treated with curcumin. Expression levels of other genes such as caspase 9 and collagen 4 A2 were upregulated in both MCF-10F and Tumor2-treated cell lines. Integrin $\alpha 5$ and cathepsin $\mathrm{B}$ and $\mathrm{D}$ decreased its expression in Tumor2, whereas E-Cadherin, c-myc and CD44 expressions were only increased in MCF-10F. It can be concluded that metastatic genes can be affected by curcumin in cancer progression and such substance can be used in breast cancer patients with advanced disease without side-effects commonly observed with therapeutic drugs.
\end{abstract}

Correspondence to: Dr Debasish Roy, Department of Natural Sciences, Hostos College, The City University of New York, A-507E, 500 Grand Concourse, Bronx, NY 10451, USA

E-mail: droy@hostos.cuny.edu

Abbreviations: IR, ionizing radiation; HBEC, human breast epithelial cell; LET, linear energy transfer

Key words: estrogen, radiation, metastatic microarray, breast cancer

\section{Introduction}

Breast cancer remains the second most common cancer worldwide with nearly 1.7 million new cases in 2012 (1). In cancer treatment, radiotherapy, alone or in a combination with chemotherapy, is widely used after surgery with proven therapeutic efficacy manifested by reduced incidence of loco-regional and distant recurrences (2-4). However, clinical evidence indicates that relapses occurring after radiotherapy are associated with increased metastatic potential and poor prognosis in breast $(5,6)$ and other tissues $(7,8)$. This has also been confirmed experimentally in tumors growing within a previously irradiated mammary tissue that is more invasive and metastasized (9-11).

Metastasis is a complex, multistep biological process, involving a multitude of genes and biomolecules. Despite the successful therapeutic management of breast cancer to control primary tumor growth, metastatic disease remains the greatest clinical challenge in oncology, as there are still not very efficient methods to prevent relapses and check the breast cancer metastasis. The interactions between cancer cells and normal host cells contribute significantly to the metastatic cascade, and a wide range of signaling and stimulating biomolecules and genes are involved in this process. Various authors have showed that heterogeneous nature of breast carcinomas that are not only characterized on the basis of histopathological features but can also be subdivided based on metastases geneexpression analysis (12-14)

Cancer metastases are responsible for the majority of cancer-related deaths. It usually arises from few cells in the primary tumor that acquire the ability to progress by sequential steps necessary to grow at a distant site $(15,16)$. Some of these sequential steps include invasion through extracellular matrix, intravasation, survival in the circulation, extravasation into a distant site, and progressive growth at that site (16).

Although early-stage breast cancer is highly treatable, no effective treatment is available for metastatic breast cancer that follows surgery, radiation and chemotherapy for the primary tumor. In breast cancer, for example, metastasis affects the bone and the lung, and less frequently the liver, brain and adrenal medulla. Although, the genetic basis of these differential metastatic properties are poorly understood, acquisition of the ability to complete each step involved in metastasis is 
thought to be driven by the accumulation of genetic mutations. These rare mutations are acquired at relatively late stage of the disease during the evolution of the primary tumor $(17,18)$. Among the anticarcinogenic and antiproliferative agents, curcumin [1,7-bis(4-hydroxy-3-methoxyphenyl)-1,6-heptadiene-3,5-dione;diferuloylmethane] is a well-known major dietary natural yellow pigment derived from the rhizome of the herb Curcuma longa (Zingiberaceae) (19). This phytochemical has also been shown to suppress the proliferation of numerous types of tumor cells $(20,21)$. It has been previously shown to prevent the formation of many chemically-induced cancers including mammary cancer in mice $(22,23)$. Metastatic development in human mammary epithelial carcinoma MCF-7 cells was also found to be inhibited by curcumin via the suppression of urokinase-type plasminogen activator by $\mathrm{NF}-\kappa \mathrm{B}$ signaling pathways (24). It is also a potent blocker of NF- $\mathrm{NB}$ activation induced by different inflammatory stimuli through inhibition of various cell cycle pathways, thus resulting in the suppression of NF- $\mathrm{BB}$-dependent gene products that suppress apoptosis and mediate proliferation, invasion and angiogenesis (25-28). The human multidrug-resistant breast cancer cell line (MCF-7/ $\mathrm{TH})$ has been shown to be several-fold more sensitive to curcumin than the mammary epithelial cell line (MCF-10A). Even though both cell lines accumulated a similar amount of curcumin, a significantly higher percentage of apoptotic cells was induced in breast cancer cells compared to a very low percentage of apoptosis in mammary epithelial cells (29). The synergistic mechanisms of combinatorial treatment using curcumin and mitomycin C (MMC) on the inhibition of tumor growth were also explored by differential gene expression profile, Gene Ontology (GO), Ingenuity Pathway Analysis (IPA) and Signal-Net network analysis (30).

The development of DNA microarray technology of genome-wide transcriptomic profiling, has provided new insight into the genetic basis of metastasis The human tumor metastasis GE Array represents $\sim 84$ genes related to metastasis and it was utilized to study the effect of curcumin on radiation-induced breast cell model $(31,32)$. Genes selected for this array encode several classes of growth factor receptors, cell-matrix interaction molecules, metastasis-associated proteases and suppressors, oncogenes and various signal transduction molecules. The aim of the present study was to analyze the differential expression of metastatic genes in radiation- and estrogen-induced breast cancer cell model and the effect of curcumin on such metastatic genes reported previously in breast carcinogenesis.

\section{Materials and methods}

Breast cancer cell lines. An in vitro experimental breast cancer model (Alpha model) developed by exposure of the immortalized human breast epithelial cell line, MCF-10F to low doses of high LET (linear energy transfer) $\alpha$ particle radiation $(150 \mathrm{keV} / \mu \mathrm{m})$ and subsequent growth in the presence or absence of $17 \beta$-estradiol was used in the present study (31). The spontaneously immortalized breast epithelial cell line MCF-10F has a near diploid karyotype and is of luminal epithelial cell origin. These cells retain all the characteristics of normal epithelium in vitro, including anchoragedependence, non-invasiveness and non-tumorigenicity in the nude mice. Cell lines were grown in DMEM/F-12 (1:1) medium supplemented with antibiotics $[100 \mathrm{U} / \mathrm{mI}$ penicillin, $100 \mu \mathrm{g} / \mathrm{ml}$ streptomycin, $2.5 \mu \mathrm{g} / \mathrm{ml}$ amphotericin B (all from Life Technologies, Grand Island, NY, USA)], $10 \mu \mathrm{g}$ / $\mathrm{ml}$ and $5 \%$ equine serum (Biofluids, Rockville, MD, USA), $0.5 \mu \mathrm{g} / \mathrm{ml}$ hydrocortisone (Sigma, St. Louis, MO, USA) and $0.02 \mu \mathrm{g} / \mathrm{ml}$ epidermal growth factor (Collaborative Research, Bedford, MA, USA) (33). This model consisted of human breast epithelial cells in different stages of transformation: i) a control cell line, MCF-10F; ii) a malignant and tumorigenic cell line named Alpha5; and iii) Tumor2 derived from cells originated from a tumor after injection of Alpha5 cell line in the nude mice. The MCF-10F cell line was exposed to double doses of $60 \mathrm{cGy}$ of $\alpha$ particles and treated with estrogen before the two exposures, such cell line was called Alpha5. Tumor2 cell line was originated from this cell line after injection in the nude mice. Both cell lines were treated with curcumin (30 $\mu \mathrm{M}$ for $48 \mathrm{~h}$ ). Phenotypic characteristics of these cell lines and their genetic alterations including differentially expressed genes were previously described (31-36).

Isolation and purification of total RNA and $m R N A$. Total RNA was isolated from both the controls (MCF-10F) and Tumor 2 cell lines and curcumin-treated cell lines using TRIzol reagent (Invitrogen Corp., Long Island, NY, USA). Each sample comprising $500 \mu \mathrm{g}$ of total RNA was treated with $5 \mu \mathrm{l}$ of DNAse I (10 U/ $\mu \mathrm{l})$ (Roche Pharm., Indianapolis, IN, USA) for $60 \mathrm{~min}$ at $37^{\circ} \mathrm{C}$. Then, $10 \mathrm{X}$ Termination Mix $(0.1 \mathrm{M}$ EDTA, pH 8.0 and $1 \mathrm{mg} / \mathrm{ml}$ glycogen) (Clontech, Palo Alto, CA, USA) was used to stop the reaction. Each sample was then purified following established procedure $(32,37)$. The amount of each purified RNA sample was first measured by a spectrophotometer and then electrophoresed on denaturing formaldehyde/agarose/ethidium bromide gel, to check its quality and purity from proteins and free nucleotides. Each sample of $500 \mu \mathrm{g}$ of purified total RNA was then subjected to PolyA $^{+}$RNA analysis with the Oligotex mRNA Purification kit (Qiagen Inc., Valencia, CA, USA). PolyA ${ }^{+}$RNA was then purified following established procedures (37).

Development of $c D N A$ from $m R N A$. A sample of 0.5-1 $\mu \mathrm{g}$ of PolyA $^{+}$RNA was then used for First Strand cDNA Synthesis using the Advantage ${ }^{\mathrm{TM}}$ RT-for-PCR kit (Clontech) using oligo(dT) and random hexamer primers. Approximately $100 \mathrm{ng}$ of the First Strand cDNA Synthesis product was used for carrying out RT-PCR reactions using gene specific primers as mentioned above. The PCR amplified products were then labeled using respective primers and Biotin-16-UTP as well as RT cocktail, as before, to generate the probes, and then used for cDNA hybridization analysis.

Protein expression by immunocytochemistry. Exponentially growing cells were plated on a glass chamber slide (Nunc Inc., Naperville, IL, USA), at a density of $1 \times 10^{4}$ cells $/ \mathrm{ml}$ of medium, and allowed to grow until $70 \%$ confluence. Cells were fixed with buffered paraformaldehyde, incubated with $1 \% \mathrm{H}_{2} \mathrm{O}_{2}$ in methanol to block endogenous peroxidase and washed with buffer solution, then covered with normal horse serum for $30 \mathrm{~min}$, and then tested with mouse TGF- $\alpha$ (C-18; sc-1338), TGF $\beta 1$ (H-112; sc-7892), E-Cadherin (H-108; 7870) and 
cathepsin D (E-7; sc-13148) monoclonal antibodies (Santa Cruz Biotechnology, Inc., Santa Cruz, CA, USA) at 1:500 dilution overnight at $4{ }^{\circ} \mathrm{C}$; then incubated for $45 \mathrm{~min}$ with diluted biotinylated secondary antibody solution and Vectastin Elite ABC reagent (both from Vector Laboratories, Burlingame, CA, USA). The experiments were repeated 3 times in cells with similar passages in vitro.

cDNA expression array. GE Array Q Series Human Tumor Metastasis Array (SABiosciences/Qiagen, Bethesda, MD, USA) represents 84 genes known to be involved in metastasis. Each of these genes was amplified by polymerase chain reaction (PCR) with gene-specific primers to generate 200- to 600-bp products. Each PCR product ( $100 \mathrm{ng}$ ) that was spotted in quadruplicate onto a positively charged membrane. Each GEArray Q series membrane was spotted with a negative control of pUC18 DNA, blanks and housekeeping genes, including $\beta$-actin, GAPDH, cyclophilin A and ribosomal protein L13A (32).

Synthesis of cDNA probes from mRNA. The purified mRNAs were used for the synthesis of cDNA probes with Biotin-16-dUTP (Roche Pharm.). Annealing mixture was prepared by mixing $\sim 1.0-5.0 \mu \mathrm{g}$ of mRNA with $3 \mu \mathrm{l}$ of Buffer A (GE primer mix) (SABiosciences) and the final volume was adjusted to $10 \mu$ l. The mixture was then incubated in a preheated thermal cycler at $70^{\circ} \mathrm{C}$ for $3 \mathrm{~min}$. Cooled to $42^{\circ} \mathrm{C}$ and kept at that temperature for $2 \mathrm{~min}$. Then, $10 \mu \mathrm{l}$ of RT cocktail was prepared by mixing $4 \mu 1$ of $5 \mathrm{X}$ Buffer BN [for $50 \mu \mathrm{l} 10 \mathrm{X}$ buffer, add $1 \mu \mathrm{l}$ of $1 \mathrm{M}$ DTT and $50 \mu \mathrm{l}$ of 10X dNTP mix (5 mM dATP, dCTP, dGTP and $500 \mu \mathrm{M}$ dTTP)], $2 \mu \mathrm{l}$ of Biotin-16-UTP, $2 \mu \mathrm{l}$ of RNase-free $\mathrm{H}_{2} \mathrm{O}, 1 \mu \mathrm{l}$ of RNase inhibitor and $1 \mu \mathrm{l}$ of MMLV reverse transcriptase (both from Promega Corp., Madison, WI, USA). RT cocktail was then warmed at $42^{\circ} \mathrm{C}$ for $1 \mathrm{~min}$ and slowly mixed with $10 \mu \mathrm{l}$ of pre-warmed annealing mixture. The incubation continued at $42^{\circ} \mathrm{C}$ for $90 \mathrm{~min}$, and then labeled cDNA probe was denatured by heating at $94^{\circ} \mathrm{C}$ for $5 \mathrm{~min}$, and quickly chilled on ice. In each cell line tested, mRNA was isolated and purified from different passages, and cDNA probes were prepared from each of them and hybridized to the respective membranes. Experiments using the same mRNA preparation were repeated 3 times, and measurable, median-normalized expression values of each gene were compared to avoid false-positive signals (32).

Differential hybridization of cDNA expression array. Each array membrane was pre-wetted with $5 \mathrm{ml}$ of de-ionized water and incubated at $60^{\circ} \mathrm{C}$ for $5 \mathrm{~min}$. It was then replaced with $2 \mathrm{ml}$ of pre-warm $\left(60^{\circ} \mathrm{C}\right)$ GEAprehyb solution (GEAhyb solution with a heat-denatured sheared salmon sperm DNA at a final concentration of $100 \mu \mathrm{g} / \mathrm{ml}$ ) (SABiosciences, Bethesda, MD) and gently mixed for a few seconds. Pre-hybridization was continued at $60^{\circ} \mathrm{C}$ for $1-2 \mathrm{~h}$ with continuous gentle agitation. Approximately $0.75 \mathrm{ml}$ solution of GEAhyb was prepared by adding the entire volume of denatured cDNA probe onto GEAprehyb solution and kept at $60^{\circ} \mathrm{C}$. Then, GEAprehyb solution was replaced by GEAhyb solution and hybridization continued overnight at $60^{\circ} \mathrm{C}$ with continuous gentle agitation. Subsequently, array membranes were washed twice in wash solution 1 (2X sodium chloride sodium citrate and $1 \%$ sodium dodecyl sulfate) at $60^{\circ} \mathrm{C}$ for 15 min each with gentle agitation and then twice with solution 2 ( $0.1 \mathrm{X}$ sodium chloride sodium citrate and $0.5 \%$ sodium dodecyl sulfate) at $60^{\circ} \mathrm{C}$ for $15 \mathrm{~min}$ each with gentle agitation. To assess the reproducibility of the hybridization array assays, pair-wise comparisons between array data sets for each cell line was tested by repeated hybridization and the mRNAs prepared in different lots were analyzed in scatter plots with multiple regressions $(32,38)$. In each case, expression levels of $95 \%$ of the genes had repeated values that were within 2 -fold (32).

Chemiluminescent detection of cDNA probes. After discarding the last wash, $2 \mathrm{ml}$ of GEAblocking solution was added to each membrane and incubated for $40 \mathrm{~min}$ at room temperature with continuous agitation. Then, binding buffer was prepared by diluting alkaline phosphatase-conjugated streptavidin (AP) with $1 \mathrm{X}$ buffer F (SuperArray, Bethesda, MD, USA) in a 1:7,500 dilution. GEAblocking solution was replaced by $2 \mathrm{ml}$ of binding buffer and incubated for $10 \mathrm{~min}$ with continuous but gentle agitation. Then, membrane was washed 4 times with $4 \mathrm{ml}$ of $1 \mathrm{X}$ binding buffer $\mathrm{F}$ for $5 \mathrm{~min}$ in each washing and rinse twice with $3 \mathrm{ml}$ of rinsing buffer $\mathrm{G}$ (SuperArray). The membrane was covered with $1.0 \mathrm{ml}$ of CDP-Star chemiluminescent substrate and incubated at room temperature for 2-5 min. It was then exposed to X-ray film (Kodak BioMax MS Film; Kodak Corp., Rochester, NY, USA) with corresponding intensifying screen at room temperature for multiple exposures of 1-5 min.

Quantification of array hybridization. Quantification of hybridization signals on the expression array membranes was carried out by exposing the autoradiographic film in a densitometric scanner (model 300A; Molecular Dynamics, Sunnyvale, CA, USA). It was then estimated both with the ImageQuant (Molecular Dynamics) and ScanAlyze program (Eisen Lab). Volume quantification was performed by calculating the volume under the surface created by a 3-dimensional plot of pixel locations and pixel values as previously described $(32,38)$. All raw signal intensities were corrected for background by subtracting the signal intensity of a negative control or blank. Results were also normalized to that of a housekeeping gene. These corrected, normalized signals can then be used to estimate the relative abundance of particular transcripts. To delineate the potential signal interference between adjacent strong hybridization signals, equal-sized ellipses were drawn around each signal area (hybridization spots) using software (ImageQuant/ScanAlyze) and was then separately scanned and compared with housekeeping genes so the chances of interference between adjacent strong hybridization signals were minimized. Normalization of the expression levels of different housekeeping genes from multiple autoradiographic exposures between different hybridization experiments were carried out by taking the average signals of each of the housekeeping genes. Data from high intensity spots were chosen for further use. Median background was subtracted, and signals that were $<2.0$-fold above background level were considered too low to accurately measure and were omitted from the analysis. Signals for each individual gene were also normalized to the geometric mean of the expression level of that gene across the set of membranes being compared. 
Table I. GEArray Q series of human tumor metastasis gene array.

Functional gene grouping

Growth factors and receptors

Cell-cell and cell-matrix interaction molecules

Metastasis-associated proteases: Matrix metalloproteinases Others

Protease inhibitors

Signal transduction molecules

Oncogenes

Metastasis, suppressors

Other related genes
Gene symbols/names
CSF1 (csf-1), CSF1R (c-fms/MC-SF-R), FGF1 (a-FGF), FGF2 (b-FGF2), HGF (scatter factor), IGF2, NGFB, TGFA (TGF- $\alpha$ ), TGFB1 (TGF $\beta 1)$, VEGF, VEGFC

CAV1 (caveolin-1), CDH1 (cadherin-1/E-cadherin), COL4A2 [collagen $\alpha 2$ (IV)], ICAM5 (telencephalin), ITGA2-3, ITGA5-6, ITGA6, ITGB1, ITGB3, LAMB1 (laminin $\beta 1$ ), LAMC1 (laminin $\beta 2$ ), MICA (MUC-18), MUC1, NCAM1, PECAM1, VTN (vitronectin)

MMP1-3, MMP7-11, MMP13-16

CASP8-9, CST3 (cystatin C), CTSB (Cathepsin B), CTSD (cathepsin D), CTSL (cathepsin L), ELA2 (elastase), HPSE (heparanase), MGEA5 (meningioma hyaluronidase 5), PLAU (UPA), TMPRSS4

SERPINB2 (PaI-2), SERPINB5 (maspin), SARPINE1

(PAI-1), THBS1-S2, TIMP1-P3

LIMK1 (Lim kinase), PLAUR (uPAR), PIK3C2B, RAC1

ERBB2 (c-erb-2/neu), ETS1-2 (c-ets-1-2), ETV4 (PEA3), FES, FOS (c-fos),

HRAS (c-Ha-ras), MDM2, MYC (c-myc), RAF1, SRC (c-src)

BRMS1 (BrMS1), CD44, DCC, KAI1, KISS1 (KiSS-1), MAP2K4 [mkk4 (JNKK1)], MTA1, NM23A (NM23), NME4, PTEN

API5 (apoptosis inhibitor 5), ARHC (Rho C), EHM2, ENPP2 (autotaxin/ATX), MGAT3 and 5 (acetylglucosa-minyltransferase III and V), ODC1, PTGS2 (cox-2), S100A4 (mts-1), SNCG (BCSG1), SSP1 (osteopontin)
Mean signals were calculated from quadruplicate measurable spots, or whether 3 of the 4 spots were measurable. Then, the changed folds indicated whether a gene exhibited increased, decreased, or unchanged expression based on statistical criteria (38).

Western blot analysis. Differential expression of few genes after quantification by array were further confirmed by western blot analysis following usual procedures.

\section{Results}

The effect of curcumin on cell lines from a radiation-induced breast cell model was studied. Microarray technology allowed us to measure the relative expression of many genes in a single experiment. In the present study, two controls the MCF-10F and Tumor 2 cell lines were treated with curcumin (MCF-10F+curcumin and Tumor2+curcumin). Table I shows the genes selected for this array that encode several classes of growth factor receptors, cell-cell, cell-matrix interaction molecules, metastasis-associated proteinase, protease inhibitors, signal transduction molecules oncogenes, metastasis, suppressors and other related genes. Fig. 1 corresponds to the membranes containing the genes found in this particular array as GE Array Q Series Human Tumor Metastasis Gene Array that was used.
Results indicated that out of 84 genes, 16 were upregulated and 4 were downregulated by curcumin treatment in MCF-10F cell line, whereas, a total of 24 genes were altered with 11 upregulated and 13 downregulated by curcumin treatment in Tumor 2 cell line. In both cases, alterations of $Q \geq 2.0$ were taken into consideration whereas, 20-25 genes also showed moderate alterations in their expression $(\mathrm{Q}<1.50)$ (data not shown). The remaining 30-35 genes showed no altered expression in either group of experiments.

Table II A and B show upregulated and downregulated metastatic genes found in MCF-10F control and treated with curcumin cell lines, respectively. Fig. 2 presents differentially expressed genes found in such array, where a comparison between MCF-10F and MCF-10F plus curcumin cell lines were analyzed. Table III A and B show regulated and downregulated metastatic genes found in Tumor 2 cell line control and treated with curcumin cell lines. Fig. 3 presents differentially expressed genes found in such array, where a comparison between Tumor2 and Tumor2 plus curcumin cell lines were analyzed. Protein expression of growth factors such as TGF- $\alpha$ (Fig. 4A) was upregulated in MCF-10F cells treated with curcumin. However, it was downregulated in Tumor2 by this substance (Fig. 4B). Similar results were observed in TGF $\beta 1$ protein expression in Tumor 2 cell lines treated with curcumin (Fig. 4C and D). Among other important genes, E-Cadherin protein expression was upregulated in MCF-10 
Table II. Upregulated and downregulated metastatic genes in MCF-10F cell line treated with curcumin $(30 \mu \mathrm{M})$.

A, Upregulated metastatic genes in MCF-10F cell line treated with curcumin $(30 \mu \mathrm{M})$

\begin{tabular}{|c|c|c|c|c|c|c|c|}
\hline \multirow[b]{2}{*}{ Position } & \multirow[b]{2}{*}{ UniGene } & \multirow[b]{2}{*}{ GeneBank } & \multirow[b]{2}{*}{ Symbol } & \multirow[b]{2}{*}{ Description } & \multirow[b]{2}{*}{ Gene name } & \multicolumn{2}{|c|}{ Fold change } \\
\hline & & & & & & MCF-10F & MCF-10F+cur \\
\hline 56 & Hs.90800 & D83646 & MMP16 & $\begin{array}{l}\text { Matrix metalloproteinase } 16 \\
\text { (membrane-inserted) }\end{array}$ & MMP16 & - & $4.7(\uparrow)$ \\
\hline 86 & Hs.170009 & NM_003236 & TGFA & Transforming growth factor, $\alpha$ & TGF- $\alpha$ & - & $4.6(\uparrow)$ \\
\hline 87 & Hs.1103 & X02812 & TGFB 1 & Transforming growth factor, $\beta 1$ & TGF $\beta 1$ & - & $4.5(\uparrow)$ \\
\hline 94 & Hs.73793 & M32977 & VEGF & Vascular endothelial growth factor & VEGF & - & $3.9(\uparrow)$ \\
\hline 8 & Hs.194657 & Z13009 & CDH1 & $\begin{array}{l}\text { Cadherin } 1 \text {, type } 1, \\
\text { E-cadherin (epithelial) }\end{array}$ & E-Cadherin & - & $3.6(\uparrow)$ \\
\hline 49 & Hs.90598 & NM_000247 & MICA & $\begin{array}{l}\text { Homo sapiens MICA gene, } \\
\text { allele MUC-18 }\end{array}$ & MUC-18 & - & $3.6(\uparrow)$ \\
\hline 64 & Hs.79070 & X00364 & MYC & $\begin{array}{l}\text { v-myc avian myelocytomatosis } \\
\text { viral oncogene homolog }\end{array}$ & c-myc & - & $3.6(\uparrow)$ \\
\hline 95 & Hs.79141 & X94216 & VEGFC & $\begin{array}{l}\text { Vascular endothelial } \\
\text { growth factor-C }\end{array}$ & VEGF-C & - & $3.4(\uparrow)$ \\
\hline 47 & Hs.121502 & NM_002410 & MGAT5 & $\begin{array}{l}\text { cDNA encod } \\
\mathrm{N} \text {-acetylglucosamyltransferase- } \mathrm{V} \\
\text { (Homo sapiens) }\end{array}$ & GnT-V & - & $3.1(\uparrow)$ \\
\hline 91 & Hs.325495 & NM_003255 & TIMP2 & $\begin{array}{l}\text { Tissue inhibitor of } \\
\text { metalloproteinase } 2\end{array}$ & TIMP-2 & - & $2.8(\uparrow)$ \\
\hline 16 & Hs.211567 & NM_005215 & $\mathrm{DCC}$ & Deleted in colorectal carcinoma & $\mathrm{DCC}$ & - & $2.5(\uparrow)$ \\
\hline 71 & Hs.78146 & NM_000442 & PECAM1 & $\begin{array}{l}\text { Homo sapiens platelet endothelial } \\
\text { cell adhesion molecule (CD31 ag) }\end{array}$ & CD31 & - & $2.3(\uparrow)$ \\
\hline 5 & Hs.100641 & U60521 & CASP9 & $\begin{array}{l}\text { Caspase } 9, \text { apoptosis-related } \\
\text { cysteine protease }\end{array}$ & $\begin{array}{l}\text { Caspase } 9 \\
\text { Mch6 }\end{array}$ & - & $2.1(\uparrow)$ \\
\hline 9 & Hs.75617 & X05610 & COL4A2 & Collagen, type IV, $\alpha 2$ & Collagen 4 A2 & - & $2.0(\uparrow)$ \\
\hline 7 & Hs. 169610 & M59040 & CD44 & $\begin{array}{l}\text { CD44 antigen (homing function } \\
\text { and Indian blood group system }\end{array}$ & CD44 & - & $2.0(\uparrow)$ \\
\hline 51 & Hs. 2258 & NM_002425 & MMP10 & Matrix metalloproteinase 10 & Stromelysin 2 & - & $2.0(\uparrow)$ \\
\hline
\end{tabular}

$\mathrm{B}$, Downregulated metastatic genes in MCF-10F cell line treated with curcumin $(30 \mu \mathrm{M})$

Fold change

\begin{tabular}{|c|c|c|c|c|c|c|c|}
\hline Position & UniGene & GeneBank & Symbol & Description & Gene name $\mathrm{N}$ & $\mathrm{MCF}-10 \mathrm{~F}$ & MCF-10F+cur \\
\hline 93 & Hs.63325 & NM_019894 & TMPRSS4 & $\begin{array}{l}\text { Transmembrane protease, } \\
\text { serine } 4\end{array}$ & TMPRSS-4 & - & $5.3(\downarrow)$ \\
\hline 78 & Hs.85181 & X03484 & RAF1 & $\begin{array}{l}\text { v-raf-1 murine leukemia } \\
\text { viral oncogene homolog } 1\end{array}$ & c-raf-1 & - & $4.7(\downarrow)$ \\
\hline 34 & Hs. 265829 & M59911 & ITGA3 & $\begin{array}{l}\text { Integrin, } \alpha 3 \\
\text { (ag CD } 49 \mathrm{C}, \alpha 3 \text { sub of VLA3 rec.) }\end{array}$ & Integrin $\alpha 3$ & - & $4.0(\downarrow)$ \\
\hline 31 & Hs. 151250 & U72671 & ICAM5 & $\begin{array}{l}\text { Intercellular adhesion molecule } 5 \text {, } \\
\text { telencephalin }\end{array}$ & ICAM-5 & - & $3.4(\downarrow)$ \\
\hline $97-99$ & $\mathrm{~N} / \mathrm{A}$ & L08752 & PUC18 & PUC18 plasmid DNA & pUC18 & 1.0 & 1.0 \\
\hline $100-102$ & Blank & Blank & Blank & Blank & 0 & 0.0 & 0.0 \\
\hline $103-104$ & Hs.169476 & M33197 & GAPD & $\begin{array}{l}\text { Glyceraldehyde-3- } \\
\text { phosphate dehydrogenase }\end{array}$ & GAPDH & 1.0 & 1.0 \\
\hline $105-108$ & Hs.342389 & NM_021130 & PPIA & $\begin{array}{l}\text { Homo sapiens peptidylprolyl } \\
\text { isomerase A }\end{array}$ & Cyclophilin A & 1.0 & 1.0 \\
\hline $109-110$ & Hs.119122 & NM_012423 & RPL13A & $\begin{array}{l}\text { Ribosom. protein L13a } \\
\text { ( } 23 \text { kDa highly basic protein) }\end{array}$ & RPL13A & 1.0 & 1.0 \\
\hline $111-112$ & Hs.288061 & X00351 & ACTB & $\beta$-actin & $\beta$-actin & 1.0 & 1.0 \\
\hline
\end{tabular}




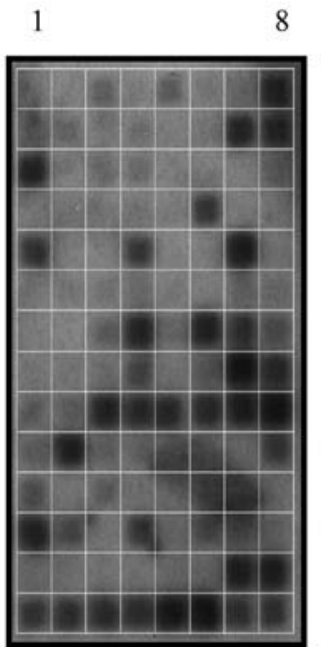

105
$8 \quad 1$

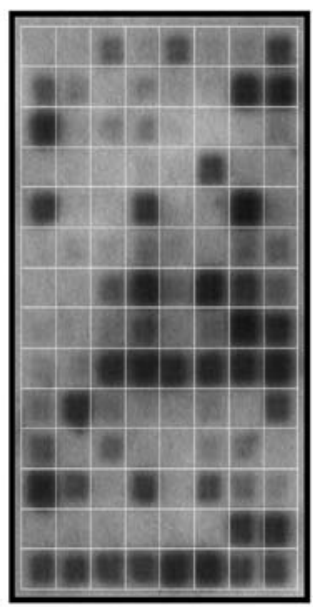

112105
8

112

MCF-10F

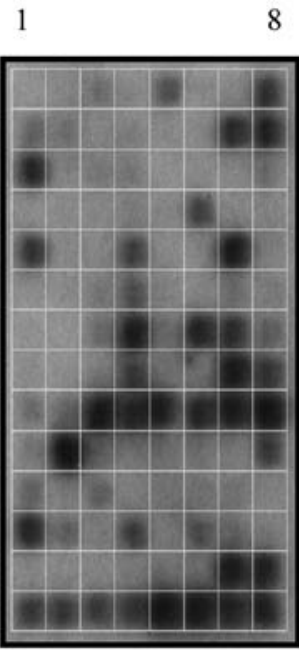

105
$8 \quad 1$

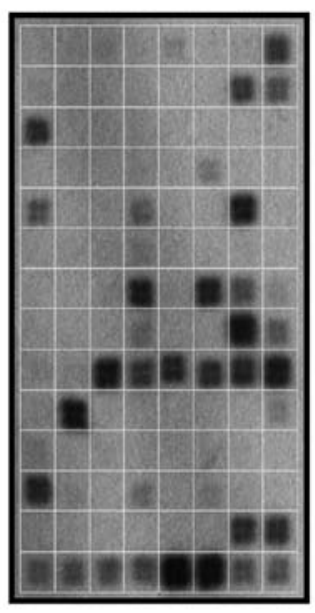

112105

112

Figure 1. GE Array Q series of human tumor metastasis gene array: Differentially expressed genes of a human tumor metastasis gene array with MCF-10F and Tumor 2 cell lines treated with curcumin, respectively.

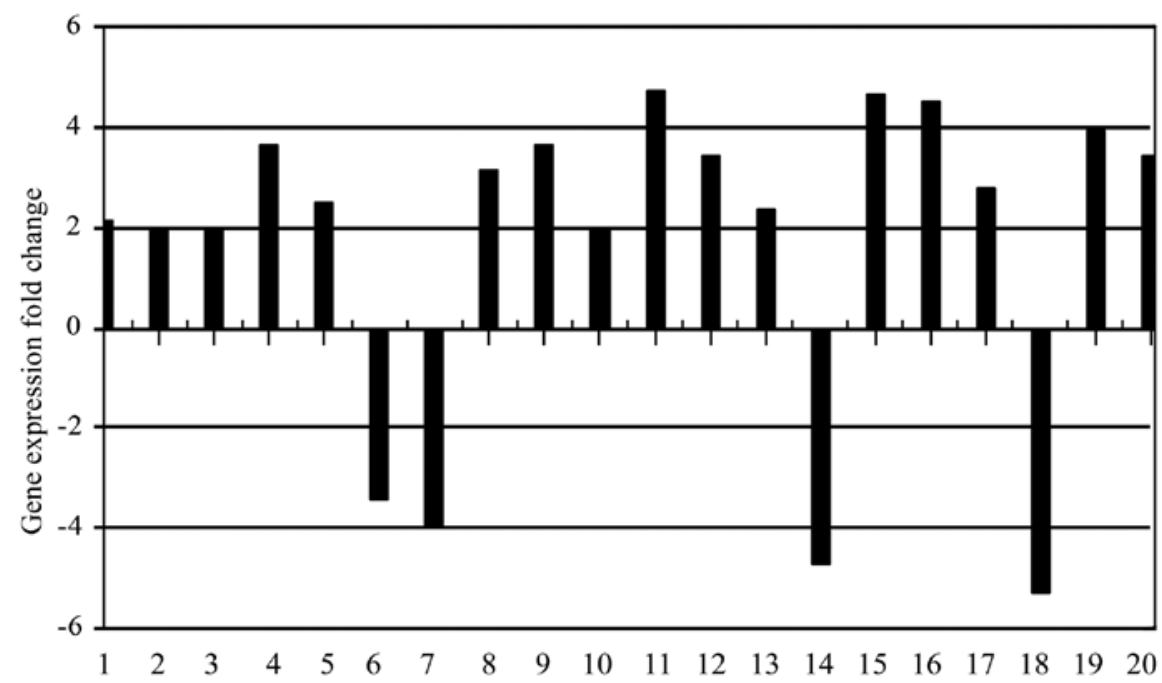

Figure 2. Graph that represents the differentially expressed genes from a human tumor metastasis gene array: a comparison between MCF-10F and MCF-10F plus curcumin cell lines.

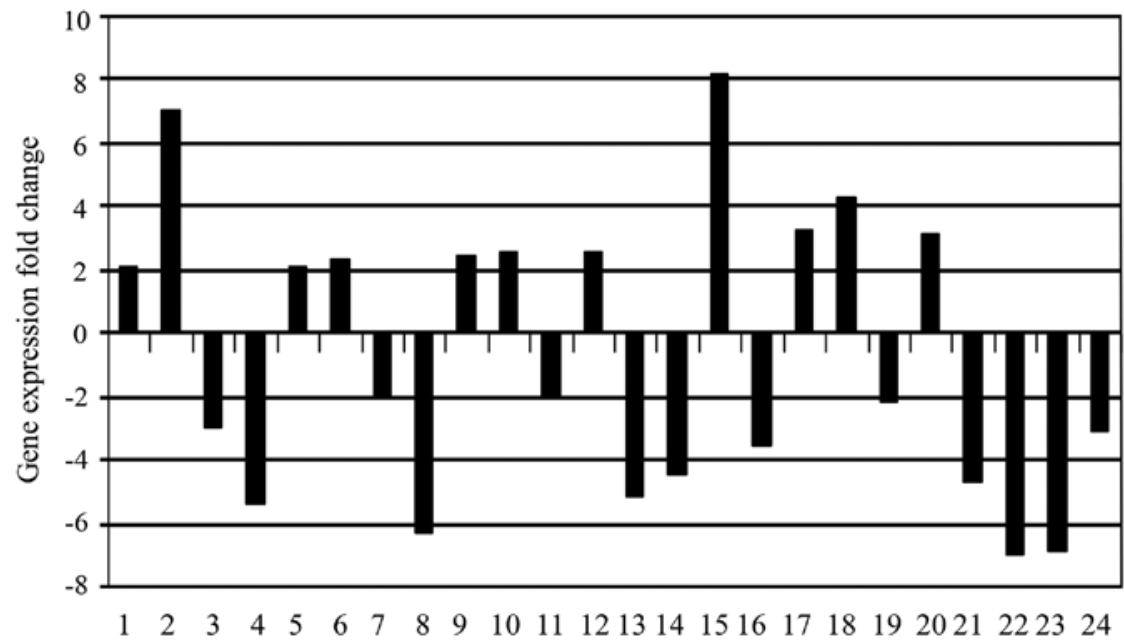

Figure 3. Graph that represents the differentially expressed genes in a human tumor metastasis gene array: a comparison between Tumor2 and Tumor2 plus curcumin cell lines. 
Table III. Upregulated and downregulated metastatic genes: Tumor 2 cell line treated with curcumin $(30 \mu \mathrm{M})$.

A, Upregulated metastatic genes: Tumor 2 cell line treated with curcumin $(30 \mu \mathrm{M})$

Fold change

\begin{tabular}{|c|c|c|c|c|c|c|c|}
\hline \multirow[b]{2}{*}{ Position } & \multirow[b]{2}{*}{ UniGene } & \multirow[b]{2}{*}{ GeneBank } & \multirow[b]{2}{*}{ Symbol } & \multirow[b]{2}{*}{ Description } & \multirow[b]{2}{*}{ Gene name } & \\
\hline & & & & & & Tumor2 & Tumor $2+$ cur \\
\hline 60 & Hs.73862 & NM_002424 & MMP8 & $\begin{array}{l}\text { Matrix metalloproteinase } 8 \\
\text { (neutrophil collagenase) }\end{array}$ & MMP8 & - & $8.2(\uparrow)$ \\
\hline 9 & Hs.75617 & X05610 & COL4A2 & Collagen, type IV, $\alpha 2$ & Collagen 4 A2 & - & $7.0(\uparrow)$ \\
\hline 76 & Hs.196384 & NM_000963 & PTGS2 & $\begin{array}{l}\text { Homo sapiens prostaglandin- } \\
\text { endoperoxide synthase } 2 \\
\text { (prostaglandin G/hsynthase } \\
\text { and cyclooxygenase) }\end{array}$ & Cox -2 & - & $4.3(\uparrow)$ \\
\hline 75 & Hs.10712 & U96180 & PTEN & $\begin{array}{l}\text { Phosphatase and tensin homolog } \\
\text { (mut in multiple Adv cancers } 1 \text { ) }\end{array}$ & PTEN & - & $3.2(\uparrow)$ \\
\hline 80 & Hs.75716 & J02685 & SERPINB2 & $\begin{array}{l}\text { Human plasminogen } \\
\text { activator inhibitor }\end{array}$ & PAI-2 & - & $3.1(\uparrow)$ \\
\hline 30 & Hs.37003 & NM_005343 & HRAS & $\begin{array}{l}\text { v-Ha-ras Harvey rat sarcoma } \\
\text { viral oncogene homolog }\end{array}$ & H-ras & - & $2.5(\uparrow)$ \\
\hline 36 & Hs. 227730 & X53586 & ITGA6 & Integrin, $\alpha 6$ subunit & Integrin $\alpha 6$ & - & $2.5(\uparrow)$ \\
\hline 28 & Hs.809 & X57574 & HGF & $\begin{array}{l}\text { Hepatocyte growth factor) } \\
\text { (hepapoietin A; scatter factor }\end{array}$ & Scatter factor & - & $2.4(\uparrow)$ \\
\hline 24 & Hs.7636 & X52192 & FES & $\begin{array}{l}\text { Proto-oncogene tyrosine- } \\
\text { protein kinase fes/fps }\end{array}$ & c-fes & - & $2.3(\uparrow)$ \\
\hline 20 & Hs.323910 & m11730 & ERBB2 & $\begin{array}{l}\text { v-erb-b2 avian erythroblastic } \\
\text { leukemia viral oncogene } \\
\text { homolog } 2\end{array}$ & erb-2 & - & $2.1(\uparrow)$ \\
\hline 5 & Hs.100641 & U60521 & CASP9 & $\begin{array}{l}\text { Caspase } 9, \text { apoptosis-related } \\
\text { cysteine protease }\end{array}$ & $\begin{array}{l}\text { Caspase 9, } \\
\text { Mch6 }\end{array}$ & - & $2.1(\uparrow)$ \\
\hline
\end{tabular}

B, Downregulated metastatic genes: Tumor 2 cell line treated with curcumin $(30 \mu \mathrm{M})$

Fold change

\begin{tabular}{|c|c|c|c|c|c|c|c|}
\hline Position & UniGene & GeneBank & Symbol & Description & Gene name & Tumor2 & Tumor $2+$ cur \\
\hline 86 & Hs.170009 & NM_003236 & TGFA & Transforming growth factor, $\alpha$ & TGF- $\alpha$ & - & $7.0(\downarrow)$ \\
\hline 87 & Hs.1103 & X02812 & TGFB1 & Transforming growth factor, $\beta 1$ & TGF $\beta 1$ & - & $6.9(\downarrow)$ \\
\hline 27 & Hs. 25647 & V01512 & FOS & Human cellular oncogene c-fos & c-fos & - & $6.3(\downarrow)$ \\
\hline 14 & Hs. 343475 & M11233 & CTSD & $\begin{array}{l}\text { Cathepsin D } \\
\text { (lysosomal aspartyl protease) }\end{array}$ & Cathepsin D & - & $5.4(\downarrow)$ \\
\hline 51 & Hs.2258 & NM_002425 & MMP10 & Matrix metalloproteinase 10 & Stromelysin 2 & - & $5.1(\downarrow)$ \\
\hline 83 & Hs.63236 & NM_003087 & SNCG & $\begin{array}{l}\text { Synuclein, } \gamma \\
\text { (breast cancer-specific protein } 1 \text { ) }\end{array}$ & BCSG1 & - & $4.7(\downarrow)$ \\
\hline 57 & Hs.111301 & J03210 & MMP2 & $\begin{array}{l}\text { Matrix metalloproteinase } 2 \\
\text { (gelatinase A, } 72 \text { kDa gelatinase) }\end{array}$ & Gelatinase A & - & $4.5(\downarrow)$ \\
\hline 66 & Hs.2561 & X52599 & NGFB & $\begin{array}{l}\text { Nerve growth factor, } \\
\beta \text { polypeptide }\end{array}$ & NGF $\beta$ & - & $3.5(\downarrow)$ \\
\hline 95 & Hs.79141 & X94216 & VEGFC & $\begin{array}{l}\text { Vascular endothelial } \\
\text { growth factor-C }\end{array}$ & VEGF-C & - & $3.1(\downarrow)$ \\
\hline 13 & Hs.297939 & L16510 & CTSB & Cathepsin B & Cathepsin B & - & $3.0(\downarrow)$ \\
\hline 26 & Hs. 284244 & NM_002006 & FGF2 & Fibroblast growth factor 2 (basic) & $\beta$-FGF & - & $2.0(\downarrow)$ \\
\hline 35 & Hs.149609 & X06256 & ITGA5 & $\begin{array}{l}\text { Integrin, } \alpha 5 \\
\text { (fibronectin receptor, } \\
\alpha \text { polypeptid) }\end{array}$ & Integrin $\alpha 5$ & - & $2.0(\downarrow)$ \\
\hline
\end{tabular}


Table III. Continued.

B, Downregulated metastatic genes: Tumor 2 cell line treated with curcumin $(30 \mu \mathrm{M})$

\begin{tabular}{|c|c|c|c|c|c|c|c|}
\hline \multirow[b]{2}{*}{ Position } & \multirow[b]{2}{*}{ UniGene } & \multirow[b]{2}{*}{ GeneBank } & \multirow[b]{2}{*}{ Symbol } & \multirow[b]{2}{*}{ Description } & \multirow[b]{2}{*}{ Gene name } & \multicolumn{2}{|c|}{ Fold change } \\
\hline & & & & & & Tumor2 & Tumor $2+$ cur \\
\hline 77 & Hs.173737 & NM_006908 & RAC1 & $\begin{array}{l}\text { Ras-rel C3 bot. toxin subs. } 1 \\
\text { (rho family, small } \\
\text { GTP bind prot.) }\end{array}$ & Rac1 & - & $2.0(\downarrow)$ \\
\hline $97-99$ & N/A & L08752 & PUC18 & PUC18 Plasmid DNA & pUC18 & 1.0 & 1.0 \\
\hline $100-102$ & Blank & Blank & Blank & Blank & 0 & 0.0 & 0.0 \\
\hline 103-104 & Hs.169476 & M33197 & GAPD & $\begin{array}{l}\text { Glyceraldehyde-3- } \\
\text { phosphate dehydrogenase }\end{array}$ & GAPDH & 1.0 & 1.0 \\
\hline 105-108 & Hs.342389 & NM_021130 & PPIA & $\begin{array}{l}\text { Homo sapiens peptidylprolyl } \\
\text { isomerase A }\end{array}$ & Cyclophilin A & 1.0 & 1.0 \\
\hline 109-110 & Hs.119122 & NM_012423 & RPL13A & $\begin{array}{l}\text { Ribosom protein L13a } \\
\text { ( } 23 \mathrm{kDa} \text { highly basic protein) }\end{array}$ & RPL13A & 1.0 & 1.0 \\
\hline 111-112 & Hs.288061 & X00351 & АCTB & $\beta$-actin & $\beta$-actin & 1.0 & 1.0 \\
\hline
\end{tabular}

A

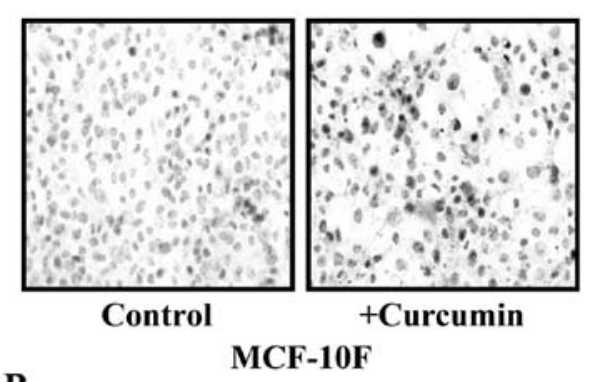

B

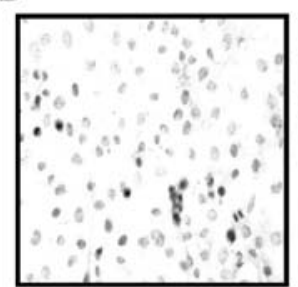

Control

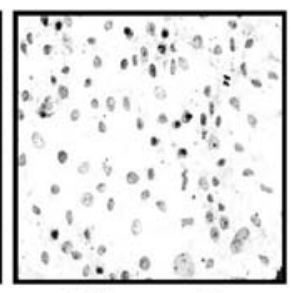

+ Curcumin

Tumor2

C

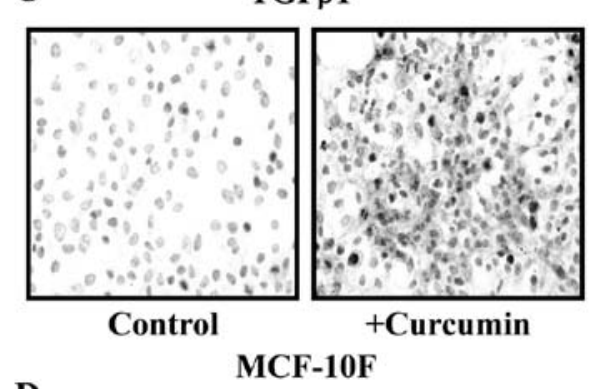

D

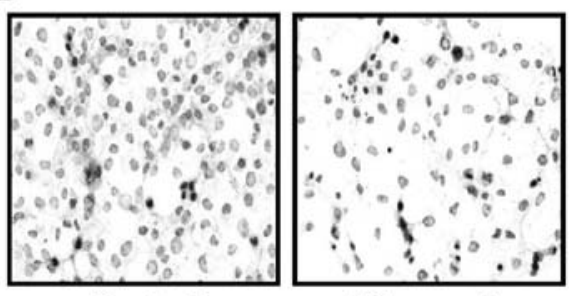

Control
+ Curcumin

Tumor2

Figure 4. Representative images of protein expression of transforming growth factor- $\alpha$ (TGF- $\alpha$ ) in: (A) MCF-10F control; (B) treated with curcumin cell lines; (C) Tumor2 and (D) treated with curcumin cell lines, respectively.

cells by the effect of curcumin and no effect in the Tumor2 cell line as shown in Fig. 5A and B). However, cathepsin D protein expression was not affected by curcumin in the MCF-10F cell line and decreased such expression in the Tumor 2 cell line as seen in Fig. 5C and D. The expression levels of few selected genes identified by cDNA microarray expression profiling were further validated by western blot analysis (Fig. 6).

\section{Discussion}

Microarray technology allows us to measure the relative expression of thousands of genes in a single experiment.
Advancement in microarray technology and gene expression databases provide a new opportunity for identifying the mode of action and targets for various genes involved in breast cancer metastatic cascade. As breast cancer is one of the most common and complex types of cancer, which frequently progress towards metastasis, microarray technique is ideal to study the genes associated with this process.

The aim of the present study was to investigate the effect of antiproliferative compound curcumin in a radiation-induced breast cancer model on genes involved in breast cancer metastasis. In the present study, the two controls MCF-10F and Tumor 2 cell lines, were used and both were treated with $30 \mathrm{mM}$ 
A

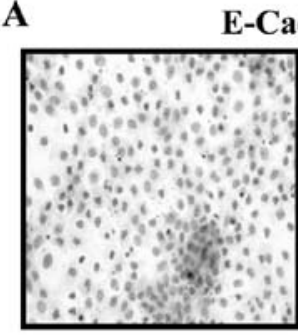

Control

B

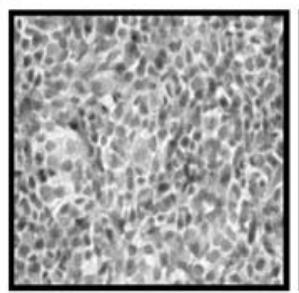

Control
E-Cadherin

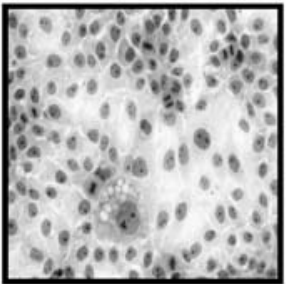

+ Curcumin

MCF-10F

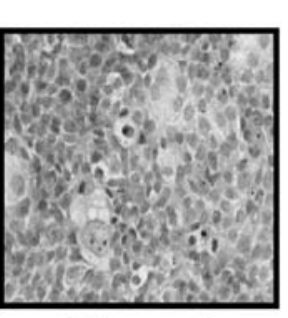

+ Curcumin

Tumor2
C

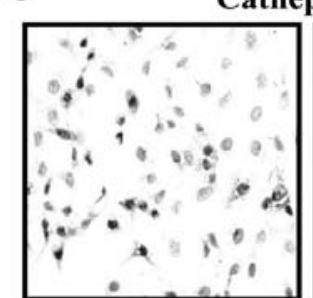

Control

$$
\text { MCF-10F }
$$

D

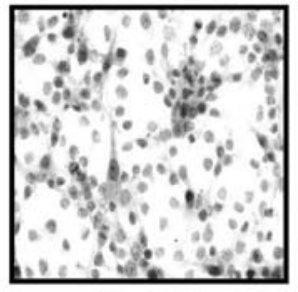

Control

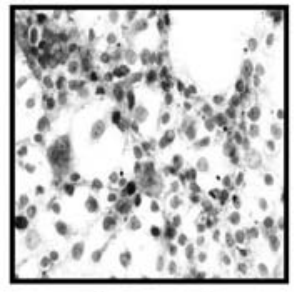

+ Curcumin
Tumor2

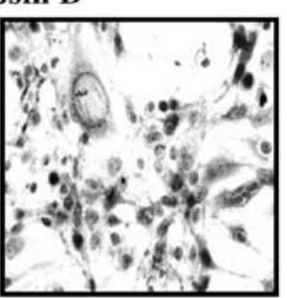

+ Curcumin

Figure 5. Representative images of protein expression of transforming growth factor $\beta$ (TGF $\beta$ ) in: (A) MCF-10F control; (B) treated with curcumin cell lines; (C) Tumor2 and (D) treated with curcumin cell lines, respectively.

\section{I) Upregulated genes}

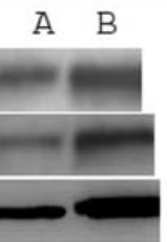

MMP16

TGF- $\alpha$

E-cadherin-

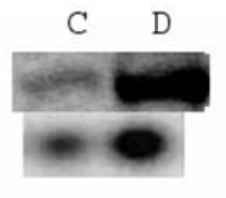

MMP8

COL4A2 
expression since it was upregulated in MCF-10F cell line and downregulated in Tumor 2 cell line in presence of curcumin. In a xenograft model of triple-negative breast cancer in mice, a lower expression of VEGFR2/3 and inhibition of angiogenesis was noted in presence of curcumin. Curcumin is known to inhibit VEGF-C induced lymphangiogenesis in a matrigel assay in mice, which is fully consistent with the result obtained in curcumin treated Tumor 2 cell line $(41,42)$. Flow cytometry and western blot analysis showed that curcumin and its derivatives induced cell cycle arrest at $\mathrm{G}_{0} / \mathrm{G}_{1}$ phase in MCF-7 cells by entering early phase of apoptosis via mitochondrial pathway, as evidenced by the activation of caspase 3 and 9, which led to elevation of intracellular ROS, a decrease in Bcl-2 and PARP and as well as an increase in Bax expression (43).

Other genes as caspase 9 and collagen 4 A2 were upregulated in both MCF-10F and Tumor2 groups. Angiogenesis is a crucial step in the growth and metastasis of cancers and the role of curcumin to act as an angiogenesis inhibitor by modulating collagen-like protease activity during endothelial morphogenesis and in few other systems are already established (44).

Several integrins (e.g., integrin $\alpha 3, \alpha 5$ and $\alpha 6$ ) showed differential expression in both cell lines. The downregulation of integrin-mediated signal transduction by curcumin treatment in Tumor 2 cell line strongly indicated the potential role of curcumin as an inhibitor of tumor cell invasion and metastasis (45). Integrins are usually cell surface markers to detect various cancer stem cell activities. Differential gene alterations of different types of integrins were noted in the analysis of the present results. It has been reported that cancer stem cells resist conventional cancer therapies and are likely to play a major role in cancer relapse by upregulating the surface markers such as integrins that leads to metastasis (46).

Other important genes usually altered in cancer progression of breast were cathepsin B and E, members of papain family of cysteine proteases normally present in the lysosome. They can be translocated and are able to degrade components of the extracellular matrix. It is interesting to note that curcumin lower protein expression of both these genes in Tumor 2 cell lines. It has been shown that an example of substrate for cathepsin B is E-Cadherin, which is involved in adherens junctions, where the downregulation of E-Cadherin in cancer is directly linked to invasion and metastasis $(47,48)$. E-Cadherin expression was only upregulated in the MCF-10F, but not in the Tumor 2 cell lines by the effect of curcumin. It is notable that such gene is related to epithelium mesenchymal transition, corroborating the epithelial phenotype that characterized E-Cadherin in such process (49).

It is concluded that metastatic genes can be affected by curcumin in cancer progression therefore it is interesting to determine that this substance can be used in breast cancer patients with advanced disease without side-effects usually induced by therapeutic drugs. Due to complex structure involving multiple functional groups, the exact mechanism and site of action of curcumin on breast cancer cells is difficult to determine and needs to be further studied.

\section{Acknowledgements}

In the present study, the technical support of Guiliana Rojas, Georgina Vargas Marchant and Leodán A Crispin is greatly appreciated. The present study was supported by grant support FONDECYT \#1120006b (to G.M.C.) and Universidad de Tarapaca-Ministerio de Educación (MINEDUC); COBI Innovation-HCC (Title-V) (to D.R.).

\section{References}

1. Ferlay J, Steliarova-Foucher E, Lortet-Tieulent J, Rosso S, Coebergh JW, Comber H, Forman D and Bray F: Cancer incidence and mortality patterns in Europe: Estimates for 40 countries in 2012. Eur J Cancer 49: 1374-1403, 2013.

2. Bartelink H, Horiot JC, Poortmans P, Struikmans H, Van den Bogaert W, Barillot I, Fourquet A, Borger J, Jager J, Hoogenraad W, et al; European Organization for Research and Treatment of Cancer Radiotherapy and Breast Cancer Groups: Recurrence rates after treatment of breast cancer with standard radiotherapy with or without additional radiation. N Engl J Med 345: 1378-1387, 2001.

3. Early Breast Cancer Trialists' Collaborative Group (EBCTCG); Darby S, McGale P, Correa C, Taylor C, Arriagada R, Clarke M, Cutter D, Davies C, Ewertz M, Godwin J, et al: Effect of radiotherapy after breast-conserving surgery on 10-year recurrence and 15-year breast cancer death: Meta-analysis of individual patient data for 10,801 women in 17 randomized trials. Lancet 378: 1707-1716, 2011.

4. Le Scodan R, Stevens D, Brain E, Floiras JL, Cohen-Solal C, De La Lande B, Tubiana-Hulin M, Yacoub S, Gutierrez M, Ali D, et al: Breast cancer with synchronous metastases: Survival impact of exclusive locoregional radiotherapy. J Clin Oncol 27: 1375-1381, 2009.

5. Mattsson A, Rudén BI, Hall P, Wilking N and Rutqvist LE: Radiation-induced breast cancer: Long-term follow-up of radiation therapy for benign breast disease. J Natl Cancer Inst 85: $1679-1685,1993$.

6. Goldstein NS, Kestin L and Vicini F: Factors associated with ipsilateral breast failure and distant metastases in patients with invasive breast carcinoma treated with breast-conserving therapy. A clinicopathologic study of 607 neoplasms from 583 patients. Am J Clin Pathol 120: 500-527, 2003.

7. O'Brien CJ, Smith JW, Soong SJ, Urist MM and Maddox WA: Neck dissection with and without radiotherapy: Prognostic factors, patterns of recurrence, and survival. Am J Surg 152: 456-463, 1986.

8. Vikram B, Strong EW, Shah JP and Spiro R: Second malignant neoplasms in patients successfully treated with multimodality treatment for advanced head and neck cancer. Head Neck Surg 6: 734-737, 1984.

9. Barcellos-Hoff MH and Ravani SA: Irradiated mammary gland stroma promotes the expression of tumorigenic potential by unirradiated epithelial cells. Cancer Res 60: 1254-1260, 2000.

10. Lemay R, Archambault M, Tremblay L, Bujold R, Lepage M and Paquette B: Irradiation of normal mouse tissue increases the invasiveness of mammary cancer cells. Int J Radiat Biol 87: 472-482, 2011.

11. Bouchard G, Bouvette G, Therriault H, Bujold R, Saucier C and Paquette B: Pre-irradiation of mouse mammary gland stimulates cancer cell migration and development of lung metastases. Br J Cancer 109: 1829-1838, 2013.

12. Perou CM, Sørlie T, Eisen MB, van de Rijn M, Jeffrey SS, Rees CA, Pollack JR, Ross DT, Johnsen H, Akslen LA, et al: Molecular portraits of human breast tumours. Nature 406: 747-752, 2000.

13. Sørlie T, Perou CM, Tibshirani R, Aas T, Geisler S, Johnsen H, Hastie T, Eisen MB, van de Rijn M, Jeffrey SS, et al: Gene expression patterns of breast carcinomas distinguish tumor subclasses with clinical implications. Proc Natl Acad Sci USA 98: 10869-10874, 2001.

14. Kozłowski J, Kozłowska A and Kocki J: Breast cancer metastasis - insight into selected molecular mechanisms of the phenomenon. Postepy Hig Med Dosw Online 69: 447-451, 2015.

15. Smid M, Wang Y, Zhang Y, Sieuwerts AM, Yu J, Klijn JG, Foekens JA and Martens JW: Subtypes of breast cancer show preferential site of relapse. Cancer Res 68: 3108-3114, 2008.

16. Weigelt B, Glas AM, Wessels LF, Witteveen AT, Peterse JL and van't Veer LJ: Gene expression profiles of primary breast tumors maintained in distant metastases. Proc Natl Acad Sci USA 100: 15901-15905, 2003. 
17. Klein CA: Gene expression signatures, cancer cell evolution and metastatic progression. Cell Cycle 3: 29-31, 2004.

18. Sato F, Saji S and Toi M: Genomic tumor evolution of breast cancer. Breast Cancer 23: 4-11, 2016.

19. Aggarwal BB, Kumar A and Bharti AC: Anticancer potential of curcumin: Preclinical and clinical studies. Anticancer Res 23: 363-398, 2003

20. Korutla L and Kumar R: Inhibitory effect of curcumin on epidermal growth factor receptor kinase activity in A431 cells. Biochim Biophys Acta 1224: 597-600, 1994.

21. Surh YJ, Han SS, Keum YS, Seo HJ and Lee SS: Inhibitory effects of curcumin and capsaicin on phorbol ester-induced activation of eukaryotic transcription factors, NF-kappaB and AP-1. Biofactors 12: 107-112, 2000

22. Shiri S, Alizadeh AM, Baradaran B, Farhanghi B, Shanehbandi D, Khodayari S, Khodayari H and Tavassoli A: Dendrosomal curcumin suppresses metastatic breast cancer in mice by changing $\mathrm{m} 1 / \mathrm{m} 2$ macrophage balance in the tumor microenvironment. Asian Pac J Cancer Prev 16: 3917-3922, 2015.

23. Farhangi B, Alizadeh AM, Khodayari H, Khodayari S, Dehghan MJ, Khori V, Heidarzadeh A, Khaniki M, Sadeghiezadeh $M$ and Najafi F: Protective effects of dendrosomal curcumin on an animal metastatic breast tumor. Eur J Pharmacol 758: 188-196, 2015

24. Zong H, Wang F, Fan QX and Wang LX: Curcumin inhibits metastatic progression of breast cancer cell through suppression of urokinase-type plasminogen activator by NF-kappa B signaling pathways. Mol Biol Rep 39: 4803-4808, 2012.

25. Aggarwal BB, Shishodia S, Takada Y, Banerjee S, Newman RA, Bueso-Ramos CE and Price JE: Curcumin suppresses the paclitaxel-induced nuclear factor-kappaB pathway in breast cancer cells and inhibits lung metastasis of human breast cancer in nude mice. Clin Cancer Res 11: 7490-7498, 2005.

26. Aggarwal S, Ichikawa H, Takada Y, Sandur SK, Shishodia S and Aggarwal BB: Curcumin (diferuloylmethane) down-regulates expression of cell proliferation and antiapoptotic and metastatic gene products through suppression of IkappaBalpha kinase and Akt activation. Mol Pharmacol 69: 195-206, 2006.

27. Shishodia S, Amin HM, Lai R and Aggarwal BB: Curcumin (diferuloylmethane) inhibits constitutive NF-kappaB activation, induces G1/S arrest, suppresses proliferation, and induces apoptosis in mantle cell lymphoma. Biochem Pharmacol 70 700-713, 2005.

28. Siwak DR, Shishodia S, Aggarwal BB and Kurzrock R Curcumin-induced antiproliferative and proapoptotic effects in melanoma cells are associated with suppression of IkappaB kinase and nuclear factor kappaB activity and are independent of the B-Raf/mitogen-activated/extracellular signal-regulated protein kinase pathway and the Akt pathway. Cancer 104: 879-890, 2005.

29. Ramachandran C and You W: Differential sensitivity of human mammary epithelial and breast carcinoma cell lines to curcumin Breast Cancer Res Treat 54: 269-278, 1999.

30. Zhou QM, Chen QL, Du J, Wang XF, Lu YY, Zhang H and Su SB Synergistic effect of combinatorial treatment with curcumin and mitomycin $\mathrm{C}$ on the induction of apoptosis of breast cancer cells: A cDNA microarray analysis. Int J Mol Sci 15: 16284-16301, 2014.

31. Calaf GM and Hei TK: Establishment of a radiation- and estrogeninduced breast cancer model. Carcinogenesis 4: 769-776, 2000

32. Roy D, Calaf G and Hei TK: Profiling of differentially expressed genes induced by high linear energy transfer radiation in breast epithelial cells. Mol Carcinog 31: 192-203, 2001.

33. Calaf G and Hei TK: Oncoprotein expression in human breast epithelial cells transformed by high-LET radiation. Int J Radiat Biol 77: 31-40, 2001.
34. Calaf GM and Roy D: Gene and protein expressions induced by $17 \beta$-estradiol and parathion in cultured breast epithelial cells. Mol Med 13: 255-265, 2007.

35. Calaf GM, Roy D and Hei TK: Immunochemical analysis of protein expression in breast epithelial cells transformed by estrogens and high linear energy transfer (LET) radiation. Histochem Cell Biol 124: 261-274, 2005.

36. Calaf GM, Alvarado ME and Hei TK: Beta catenin is associated with breast cancer progression in vitro. Int J Oncol 26: 913-921, 2005.

37. Sambrook J, Fritsch EF and Maniatis T: Molecular Cloning: A Laboratory Manual. 3rd edition. Cold Spring Harbor Laboratory Press, Cold Spring Harbor, NY, 1989.

38. Liu WM, Mei R, Di X, Ryder TB, Hubbell E, Dee S, Webster TA, Harrington CA, Ho MH, Baid J, et al: Analysis of high density expression microarrays with signed-rank call algorithms. Bioinformatics 18: 1593-1599, 2002.

39. Sartorius CA, Hanna CT, Gril B, Cruz H, Serkova NJ, Huber KM, Kabos P, Schedin TB, Borges VF, Steeg PS, et al: Estrogen promotes the brain metastatic colonization of triple negative breast cancer cells via an astrocyte-mediated paracrine mechanism. Oncogene 10: 1038-1053, 2015.

40. Wright LE, Frye JB, Lukefahr AL, Timmermann BN, Mohammad KS, Guise TA and Funk JL: Curcuminoids block TGF- $\beta$ signaling in human breast cancer cells and limit osteolysis in a murine model of breast cancer bone metastasis. J Nat Prod 76: 316-321, 2013.

41. Ferreira LC, Arbab AS, Jardim-Perassi BV, Borin TF, Varma NR, Iskander AS, Shankar A, Ali MM and Zuccari DA: Effect of curcumin on pro-angiogenic factors in the xenograft model of breast cancer. Anticancer Agents Med Chem 15: 1285-1296, 2015.

42. Wang W, Sukamtoh E, Xiao H and Zhang G: Curcumin inhibits lymphangiogenesis in vitro and in vivo. Mol Nutr Food Res 59: 2345-2354, 2015.

43. Mohankumar K, Pajaniradje S, Sridharan S, Singh VK, Ronsard L, Banerjea AC, Benson CS, Coumar MS and Rajagopalan R: Mechanism of apoptotic induction in human breast cancer cell, MCF-7, by an analog of curcumin in comparison with curcumin - an in vitro and in silico approach. Chem Biol Interact 210: 51-63, 2014.

44. Thaloor D, Singh AK, Sidhu GS, Prasad PV, Kleinman HK and Maheshwari RK: Inhibition of angiogenic differentiation of human umbilical vein endothelial cells by curcumin. Cell Growth Differ 9: 305-312, 1998.

45. Mitra A, Chakrabarti J, Banerji A, Chatterjee A and Das BR: Curcumin, a potential inhibitor of MMP-2 in human laryngeal squamous carcinoma cells HEp2. J Environ Pathol Toxicol Oncol 25: 679-690, 2006.

46. Prud'homme GJ: Cancer stem cells and novel targets for antitumor strategies. Review. Curr Pharm Des 18: 2838-2849, 2012.

47. Sun T, Jiang D, Zhang L, Su Q, Mao W and Jiang C: Expression profile of cathepsins indicates the potential of cathepsins B and D as prognostic factors in breast cancer patients. Oncol Lett 11: $575-583,2016$.

48. Ruan H, Hao S, Young P, Zhang H: Targeting cathepsin B for cancer therapies. Horiz Cancer Res 56: 23-40, 2015.

49. Chen CC, Sureshbabul M, Chen HW, Lin YS, Lee JY, Hong QS, Yang YC and Yu SL: Curcumin suppresses metastasis via Sp-1, FAK inhibition, and E-Cadherin upregulation in colorectal cancer. Evid Based Complement Alternat Med 2013: 541695, 2013. 